Green $S$ \& Hartweg $J$

\title{
A SITUATION ANALYSIS OF HOSPITALISED PHYSICALLY ABUSED PRE-SCHOOL CHILDREN IN SOUTH AFRICA: CONTRIBUTING SOCIAL FACTORS
}

Prof Sulina Green is Chair of the Department of Social Work at the University of Stellenbosch and Ms Janine Hartweg was a MA-student in the Department of Social Work at the University of Stellenbosch at the time of writing the article.

\begin{abstract}
The experience of physical abuse is a traumatic event, which is so intense and frightening that it overwhelms the child's ability to cope with his/her normal developmental tasks. The goal of the study was to expand social worker's knowledge of the social circumstances of physically abused preschool children who are hospitalised, and to offer guidelines for professionals from a variety of disciplines to identify and assess physical abuse. To obtain the goals, the objectives were threefold: first to present demographic data on children with intentional physical injuries and their families; second, to describe the experiences of the perpetrators and circumstances under which the abuse took place; and third, to determine how social workers assess children who are suspected of having been physically abused. The study was conducted at the Red Cross Children's Hospital in Cape Town, South Africa. Both qualitative and quantitative methods were applied. The diagnoses reported were drawn from a sample of preschool aged children presenting with intentional physical injuries at the hospital over a four month period, interviews with four perpetrators using set guidelines, and conducting a survey with four of the social workers employed at the hospital using a self-completion questionnaire. The findings offered demographic details of the abused children and confirmed that children under the age of six were the most vulnerable age group to be subjected to physical abuse. Head injuries and gunshot wounds were the most frequent occurring physical injuries in this sample, indicating gang activities, effects of poverty and substance misuse. Four case studies are presented following the interviews with the perpetrators/parents, which give a situation analysis of these social circumstances under which the abuse took place. The social circumstances under which the physical abuse took place, and criteria used for assessment can be used as a framework for professionals rendering services to children.
\end{abstract}

\section{INTRODUCTION}

The experience of physical abuse is a traumatic event, which is so intense and frightening that it overwhelms the child's ability to cope with his/her normal developmental tasks. This experience is damaging to the mental health of the child, which has negative effects on the development of the child (Lewis, 1999:6).

Intentional injuries inflicted on children are not a new phenomenon, and yet, it is only in the last century that professionals have been raising public awareness in the responsibility society has for protecting abused children (Brissett-Chapman, 1995:354).

Early awareness in the $20^{\text {th }}$ century led to the United Nations Declaration of the Rights of the Child, which includes a clause protecting children from cruelty and neglect. South Africa ratified this document on 16 June 1995, and the rights of the child are provided for in Article 28, of the Constitution of South Africa, Act 108 of 1996. 
The increasing awareness of child abuse has increased demands for service provision (Argent, Bass \& Lachman, 1995:1317). The Department of Health in South Africa has therefore made services to children a priority, as is clear from the White Paper for Transformation of the Health System (1997:13). However, there seems to be a lack of research done on the circumstances and overall profile of abused children in South Africa.

The Child Care Amendment Act (96/96) of South Africa has extended the obligation for other professionals outside the medical field (such as teachers, nursery school and crèche teachers, people employed in places of safety and children's homes) to report cases of suspected child abuse.

Consequently, reports of incidents of physically abused children have increased, and these disclosures reveal ever more severe forms of physical abuse to children, in terms of the injuries that are inflicted. The statistics given by the South African Police indicate an increase in reports on abused children. In 1998 in the Western Cape alone, 478 cases of child abuse were reported. In 1999 this number increased to 532, which shows an increase of $10 \%$ within one year.

And yet, there still appear to be problems in identifying and thus reporting physically abused children to the authorities (Peltzer \& Phaswana 2000). According to Brissett-Chapman (1995:354), social workers are usually ill equipped to tackle the assessment of physically abused children, which Peltzer and Phaswana (2000:75) indicate is often the reason for certain cases of physically abused children not being reported. Social workers and professionals in a hospital setting rendering services to physically abused children appear to lack guidelines on how to assess the child and the family.

Extensive research has been done on the risk factors that contribute to child abuse (Ross, 1996:592), and on the effects of physical abuse on young children (Briere, 1992:7; Gallagher, Leavitt \& Kimmel, 1995:3; Monaghan-Blout, 1996:47; Mullen, Martin, Anderson, Romans \& Herbison, 1996:7; Prino \& Peyrot, 1994:871).

The study compliments two other projects undertaken about child abuse in hospitals in South Africa. Firstly, Louw, Schalkwyk, Barnes, Dhansay and Schaaf (1999:301) investigated the social work experience of child abuse and neglect at Tygerberg Hospital. They stated that cases of physical abuse were usually missed in the hectic Trauma Unit, and children were often discharged without being referred to the Social Work Department (Louw et al., 1999:310). Secondly, The Pediatric Unit of Groote Schuur Hospital conducted research at Red Cross Children's Hospital in 1995, on services for abused children (Argent et al., 1995:1313).

The Social Work Departments of the three main hospitals in the Western Cape Province in South Africa namely Groote Schuur, Tygerberg and Red Cross Children's Hospital, stated the need for research to be done on physically abused children. There is a high incidence of such cases, and information is needed on the social circumstances of these children.

This research developed from the need expressed by these hospitals, the development and implementation of recent legislation as indicated above, as well as from Coohey and Braun's (1997:1081) who suggested the need for further research to be done on the interdependencies of domestic violence and child physical abuse, with special reference to the social circumstances under which the abuse takes place. Smith, Sullivan and Cohen (1995:32) also recommend that these risk factors and how they are assessed should be researched because they influence interventive decisions with physically abused children.

There were several limitations to this study. There was a limited budget four months in which to conduct this study. Although clinicians have to determine under which circumstances the abuse 
took place, the contributing factors varied across different backgrounds. Each geographical region presented its own profile, therefore information received from research done in this area may not be universally applicable. The research was only conducted in one hospital in the Western Cape Province.

The results of the research was intended to provide information about contributing factors, family circumstances and the different cultural backgrounds of children with intentional physical injuries who are hospitalised. This research will give specific information on physical child abuse identified at Red Cross Children's Hospital, which will be relevant to the clinicians intervening in that area, but will also equip other professionals working with children to identify, assess and report physical abuse. The information can increase multi-disciplinary co-operation and an overlap of services, which is important for South African services, as resources are limited (Hartweg 2001). The information may thus be relevant to similar developing countries.

\section{METHODS}

\section{Methodology}

Children presenting with physical injuries are often hospitalised, and there is an increase in cases of children being admitted to the hospital who have been physically abused (Hartweg, 2001). The research was conducted at the Red Cross Children's Hospital in the Western Cape Province, as it is the only comprehensive children's hospital in South Africa (Argent et al., 1995:1314). It is also the primary care facility and major paediatric referral centre for children in the Western Cape Province and renders services to three million people in Cape Town.

An exploratory study was undertaken. The aim was to develop insight and understanding about the field of study (Williams, Tutty \& Grinnell, 1995:119). Both qualitative and quantitative methods were applied.

\section{Sampling and data gathering}

Data was gathered in different ways from the same respondents to get a complete analysis, a method known as a panel survey (Dooley, 1995:125). The research was conducted in three phases, which are indicated below.

\section{Profile of physically abused children and their families}

Respondents were chosen according to specific characteristics as well as willingness to participate, a method known as purposive sampling (Dooley, 1995:136). The sample was drawn from the paediatric patient population at the Red Cross Hospital, and focused on children under the age of six presenting with diagnosed intentional physical injuries. A profile on the identifications and circumstances of the physically abused children was drawn up over a four-month period from May to August 2000. This information was obtained from the files of the patients. Over the four month period, only 24 children $(\mathrm{N}=24)$ under the age of six presented with diagnosed intentional physical injuries. Samples were not taken from children presenting with queries of physical abuse.

\section{Case studies of the parents/perpetrators}

The qualitative part of the study included four case studies of parents. The small sample was due to several factors. Participation was on a voluntary basis. The topic of discussion was of a sensitive nature and personal involvement of the parents as perpetrators meant that only four parents were willing to participate. These parents were also perpetrators of the physically abused child. The perpetrating parents participated in semi-structured interviews, with a view for the 
researcher to gain in-depth information on the family dynamics and social circumstances under which the physical abuse took place within the nucleus family.

\section{Survey with the social workers}

There were seven $(\mathrm{N}=7)$ social workers in the hospital, of which two were absent during the time that the survey was conducted. Data was gathered from five social workers $(n=5)$ who assessed the cases of suspected physical abuse. The social workers were given questionnaires in order to obtain information on assessment strategies and problems. The questionnaires were divided into six sections, and contained structured and open-ended questions.

\section{Participants}

Participation by the respondents was voluntary and written informed consent was obtained. All personal information was kept confidential. Additional permission to conduct the study with the participants and to access files was obtained from the Review Board and Superintendent at Red Cross Children's Hospital.

Argent et al. (1995:1314) mentions that since Red Cross serves a diverse community and is also the main paediatric referral centre for the Cape Metropolitan area, and therefore the families that were involved in the research were a fair representation of the population.

Non-probability sampling was used, as the researcher played a role in choosing the sample (Grinnell \& Williams, 1990:125).

\section{RESULTS}

There is no single explanation or formula that can be applied to explain or help identify physical abuse. It is also not always easy to identify physical manifestations of an injury as intentional (Brissett-Chapman, 1995:359; Warner \& Hansen, 1994:12). The authors also state that identifying and assessing the abuse of a child was traditionally an informal process lead by an individual worker, where personal bias often caused faulty decisions. More consistent ways have to be found for working in a hospital setting to understand and intervene in child physical abuse cases. Factors associated with identification of abuse in order to report it, are crucial and will thus be discussed under the three stages in which the research was conducted.

\section{Profile of the children}

This formed the first part of the study, in which a profile was taken of all children $(\mathrm{N}=24)$ admitted to the hospital over a four month period. The following factors were the main indicators of vulnerability of these children.

Age

Of the children who presented with intentional physical injuries, 19 or $79,17 \%$, were under the age of six, and the remaining five $(20,83 \%)$ were between the ages of $8-11$. This finding corresponds with Argent et al. (1995:1316), Brissett-Chapman (1995:359), Howard, Marumo \& Coetzee (1991:394), Louw et al. (1999:301), Peltzer and Phaswana (2000:69), Warner and Hansen (1994:19) who all stated that children under the ages of five and six are a vulnerable group for physical abuse. Out of the under six age group, the highest concentration ( 7 or $29,17 \%$ ) of the abused children was under the age of one. This was also found by De Villiers and Prentice (1991:147), who explained that the very young children of under the age of three, are the most vulnerable for physical abuse. 
The age of the children is therefore important when assessing whether the injury may have been intentional, as a younger child appears to be more vulnerable to sustain intentional physical injuries.

\section{Gender}

The male victims of physical child abuse outnumbered the female victims by two (8\%). Although the findings indicate more males than females with intentional injuries, gender does not seem to be a defining factor. This was also the results indicated by Argent et al. (1995:1316) and De Villiers and Prentice (1996:149) who found that there usually is an equal distribution between male and female physically abused children.

\section{Type of injury}

TABLE 1

INJURIES INCURRED BY THE CHILDREN

\begin{tabular}{|l|c|c|}
\hline TYPE OF INJURY & f & \% \\
\hline Head injuries (haematomas/ skull fractures) & 14 & 58,33 \\
\hline Gun-shot wound & 3 & 12,53 \\
\hline Lacerations/bruises & 2 & 8,33 \\
\hline Femur/leg fracture & 2 & 8,33 \\
\hline Arm fracture & 1 & 4,16 \\
\hline Burns & 1 & 4,16 \\
\hline Stab wound & 1 & 4,16 \\
\hline TOTAL & $\mathbf{2 4}$ & $\mathbf{1 0 0}$ \\
\hline
\end{tabular}

$\mathbf{N}=\mathbf{2 4}$

Table 1 reflects the injuries most commonly incurred by the children. Fourteen $(58,33 \%)$ patients presented with head injuries that included fractured skulls and haematomas. Although Kotch, Chalmers, Fanslow, Marshall \& Langley (1993:237) state that in most cases of intentional physical injuries to children, these type of injuries are more likely to be moderate, in the form of lacerations and small fractures. The findings of this study however indicate that most children presented with severe injuries, which lead to the death of the child in five out of the fourteen $(35.8 \%)$ cases presenting with head injuries. The reason for the high incidence of severe injuries could be that it is easier to establish physical abuse in such cases than moderate ones, as a head injury is usually an overt indicator of physical abuse, according to Winship (1987:193). The findings about the occurrence of head injuries are followed in number by three $(12,53 \%)$ patients who had gunshot wounds. No mention is made in the literature of gunshot wounds, although it is the second most prevailing injury to occur in this study. Two $(8,33 \%)$ children in the sample had lacerations and bruises, and a two $(8,33 \%)$ had leg fractures. The remaining injuries were equally dispersed, with one $(4,16 \%)$ patient having an arm fracture, another one $(4,16 \%)$ patient presented with burns and a further one $(4,16 \%)$ had stab injuries. The South African National Council for Child and Family Welfare (1992:18) and Winship (1987:193) both mention that fractures in the forearms and femurs (lower legs) are indicators that the injury was intentional, as well as bruises and lacerations in unusual places, or uncommon places to incur these injuries such as the upper arm or inner thigh. Warner and Hansen (1994:18) state that to establish whether such injuries were intentional, one has to consider these in conjunction with a history of injuries and parent's explanations. 
FIGURE 1

CASE STUDIES OF FOUR PERPETRATORS

\begin{tabular}{|c|c|c|c|c|}
\hline $\begin{array}{l}\text { DEMO- } \\
\text { GRA- } \\
\text { PHICS }\end{array}$ & RESPONDENT A & RESPONDENT B & RESPONDENT C & RESPONDENT D \\
\hline Age & 29 & 28 & 26 & 18 \\
\hline Gender & Female & Male & Female & Female \\
\hline $\begin{array}{l}\text { Marital } \\
\text { Status }\end{array}$ & Married & Single & Married & Single/living together \\
\hline Children & 3, and 1 step-child & 2 & 2 & 1 \\
\hline $\begin{array}{l}\text { Back- } \\
\text { ground }\end{array}$ & $\begin{array}{l}\text { Parents abused } \\
\text { alcohol, verbal and } \\
\text { physical abuse in } \\
\text { home. }\end{array}$ & $\begin{array}{l}\text { Parents abused alcohol, } \\
\text { emotional and physical } \\
\text { abuse in home. }\end{array}$ & $\begin{array}{l}\text { Large family, children } \\
\text { from different fathers } \\
\text { and cramped housing. } \\
\text { Physical and emotional } \\
\text { abuse. }\end{array}$ & $\begin{array}{l}\text { Grew up in stepfamily, } \\
\text { was abused (sexually } \\
\text { and physically) by } \\
\text { stepfather who drank a } \\
\text { lot. }\end{array}$ \\
\hline $\begin{array}{l}\text { Housing/ } \\
\text { environ- } \\
\text { ment }\end{array}$ & $\begin{array}{l}\text { Happy with area, } \\
\text { although high crime } \\
\text { rates. Nine people live } \\
\text { in two- bedroom } \\
\text { house with her. }\end{array}$ & $\begin{array}{l}\text { Not happy in area, high } \\
\text { crime rates and } \\
\text { violence. Stays with } \\
\text { eight people in two- } \\
\text { bedroom house. }\end{array}$ & $\begin{array}{l}\text { Not happy in area, very } \\
\text { violent with a lot of } \\
\text { crime. Four People live } \\
\text { in one-bedroom shack. }\end{array}$ & $\begin{array}{l}\text { A lot of gangsterism in } \\
\text { area, not happy there, } \\
\text { but glad to stay with } \\
\text { family. Eight people in } \\
\text { two-bed roomed house. }\end{array}$ \\
\hline $\begin{array}{l}\text { Employ- } \\
\text { ment/ } \\
\text { income }\end{array}$ & $\begin{array}{l}\text { Unemployed, husband } \\
\text { does not earn enough. }\end{array}$ & Currently unemployed. & $\begin{array}{l}\text { Employed as char once } \\
\text { a week, does not earn } \\
\text { enough to survive on. }\end{array}$ & $\begin{array}{l}\text { Unemployed, only } \\
\text { works casual jobs when } \\
\text { available. }\end{array}$ \\
\hline $\begin{array}{l}\text { Social } \\
\text { environ- } \\
\text { ment }\end{array}$ & $\begin{array}{l}\text { Lives close to } \\
\text { hometown, family } \\
\text { members support. No } \\
\text { other social contact } \\
\text { than with family. }\end{array}$ & $\begin{array}{l}\text { In same neighborhood } \\
\text { as he grew up in. Family } \\
\text { and friends support him, } \\
\text { no other social contact }\end{array}$ & $\begin{array}{l}\text { Near to hometown, good } \\
\text { support from friends and } \\
\text { especially mother. } \\
\text { Sometimes social } \\
\text { contact with church, but } \\
\text { not regular. }\end{array}$ & $\begin{array}{l}\text { Close to hometown, } \\
\text { lives with family. Good } \\
\text { support from them. No } \\
\text { other socializing may } \\
\text { not leave house often. }\end{array}$ \\
\hline Family size & $\begin{array}{l}\text { Three children all } \\
\text { from the same father, } \\
3 \text { years apart which } \\
\text { helps with parenting. } \\
\text { One stepchild whom } \\
\text { she has problems } \\
\text { with. }\end{array}$ & $\begin{array}{l}\text { Two children. Extended } \\
\text { family lives in house, } \\
\text { but do not help with the } \\
\text { children anymore. } \\
\text { Children very young, } \\
\text { and not far apart in age. }\end{array}$ & $\begin{array}{l}\text { Two children, not of } \\
\text { same father. Extended } \\
\text { family (mother) stays in } \\
\text { house - she finds it has a } \\
\text { positive effect on her } \\
\text { parenting. }\end{array}$ & $\begin{array}{l}\text { One child. Extended } \\
\text { family (mother) in } \\
\text { house - finds her } \\
\text { interfering with her own } \\
\text { parenting. }\end{array}$ \\
\hline $\begin{array}{l}\text { Marital } \\
\text { Relation- } \\
\text { ship }\end{array}$ & $\begin{array}{l}\text { Do not discuss } \\
\text { anything, a lot of } \\
\text { conflict. Argue about } \\
\text { relationship and } \\
\text { finances. Husband } \\
\text { hits her at times. } \\
\end{array}$ & $\begin{array}{l}\text { N/A - but family } \\
\text { relationships between } \\
\text { people staying in the } \\
\text { house characterized by } \\
\text { conflict and physical } \\
\text { violence. }\end{array}$ & $\begin{array}{l}\text { If argue, partner leaves } \\
\text { the house refusing to } \\
\text { talk to her. Conflict } \\
\text { about another woman. } \\
\text { Has led to physical } \\
\text { violence between them. }\end{array}$ & $\begin{array}{l}\text { Boyfriend lives with } \\
\text { her, who has final say. } \\
\text { Gets angry quickly. } \\
\text { Conflict about money. } \\
\text { There is violence } \\
\text { between them. }\end{array}$ \\
\hline $\begin{array}{l}\text { Substance } \\
\text { abuse }\end{array}$ & $\begin{array}{l}\text { Alcohol consumption } \\
\text { on weekends. Has led } \\
\text { to verbal and physical } \\
\text { fights with her } \\
\text { partner, but not with } \\
\text { her own children. }\end{array}$ & $\begin{array}{l}\text { Alcohol consumption on } \\
\text { weekends, and occasio- } \\
\text { nally during the week. } \\
\text { Has caused him to get } \\
\text { physically abusive with } \\
\text { others, family members } \\
\text { and his children. }\end{array}$ & $\begin{array}{l}\text { Denies using any } \\
\text { substances. }\end{array}$ & $\begin{array}{l}\text { Only socially. Boyfriend } \\
\text { has drinking problem- } \\
\text { wastes the family's } \\
\text { money on drink. }\end{array}$ \\
\hline $\begin{array}{l}\text { Physical } \\
\text { injury to } \\
\text { child }\end{array}$ & $\begin{array}{l}\text { Injury incurred while } \\
\text { beating her stepchild, } \\
\text { in order to discipline } \\
\text { her. Caused severe } \\
\text { head injury and child } \\
\text { went into coma. Feels } \\
\text { responsible and } \\
\text { scared. }\end{array}$ & $\begin{array}{l}\text { Aimed a blow at his } \\
\text { sister while under the } \\
\text { influence of alcohol, but } \\
\text { missed and then hit his } \\
\text { child on the head, } \\
\text { causing a haematoma. }\end{array}$ & $\begin{array}{l}\text { Were arguing about the } \\
\text { other woman again. She } \\
\text { got angry and threw a } \\
\text { bottle at her husband, } \\
\text { missed him and hit the } \\
\text { child on the head. Skull } \\
\text { fracture. }\end{array}$ & $\begin{array}{l}\text { Arguing about money- } \\
\text { he spent it all on drink. } \\
\text { She lost control, } \\
\text { grabbed a stick. Hit him } \\
\text { while he was on the bed } \\
\text { with the baby-caused a } \\
\text { haematoma. }\end{array}$ \\
\hline
\end{tabular}


The findings indicated that head injuries and gun shot wounds are the most frequent form of physical abuse in hospital. It can be concluded that the type of abuse taking place in the homes is extremely violent. It also seems that moderate injuries are detected less than severe ones, which could be an indication of a lack of enquiry into seemingly minor or moderate injuries by professionals assessing the physical injuries.

\section{Social circumstances of the families in which the abuse took place}

Clinicians need to be able to identify risk factors, as this is vital during assessment of the child and his/her parent (Hartweg, 2001).

The following is a summary of the four case studies $(n=4)$ on which the second part of the study was based, which highlights the risk factors in families for physical abuse to take place. The information received from these interviews is incorporated into the general profile of the children's families $(\mathrm{N}=24)$.

\section{DISCUSSION OF THE CASE STUDIES AND RESULTS}

The information obtained during the interviews with the four respondents which is presented in the case studies is incorporated into the general profile of the children's families $(\mathrm{N}=24)$, which was taken in the first part of the study.

Although Red Cross Children's Hospital, from which the sample was taken, was the largest children's hospital in South Africa (Argent et al., 1995:1314), there were small samples available and only a limited number of respondents that participated. There were two reasons for this small sample. Firstly, Red Cross Children's Hospital employs only seven social workers, of which five were present during the time of the study in order to take part in the research. Secondly, due to the time limits and sensitive nature of the study, only four parents who were identified as perpetrators were willing to participate in the interviews.

The discussion of this information is reflected in the social factors researched below.

\section{Age}

In the sample $(\mathrm{N}=24)$ there was an equal distribution between the age categories of 20-25 and 2630 , with nine respondents in each age category. Five respondents were above the age of 30 , while only one of the perpetrators was under the age of twenty. The findings seem to be in conflict with Corby (1993:66) and Warner and Hansen (1994:21) who mention that younger parents under the age of twenty are most likely to physically abuse their children. The age group between 20 and 30 years, reflects young parents who are expected to be independent and in the employment market. Howard et al. (1991:393) and Lewis (1999:122) explain that this age group are expected to cope with family, work and financial stresses on their own, which creates a lot of tension for the parent.

From the above findings and other studies which were mentioned above, it would appear that the perpetrators are not usually young parents under twenty, but young adults between 20 and 30 years.

\section{Marital Status}

Most (fourteen) of the perpetrators $(\mathrm{N}=24)$ where single, while eight were married or living together on a permanent basis, and two were divorced. These findings correspond with the findings of Prino and Peyrot (1994:882) and Wells (1995:350) that marital status is a risk factor that can act as a guide in identifying perpetrators and intentional injuries. Both authors emphasize 
that single parents are more at risk of abusing their children, because the parents have to cope emotionally and financially on their own, without the support of a partner. Corby (1993:83) also supports this finding, and states that there is a higher incidence of physical abuse where a parent is the sole caretaker. Respondent B is a single parent. He expressed his frustration by having the sole responsibility for the children and household in the following statement:

Respondent B: "I don't know what to do. I come home, and my sister doesn't want to look after the children anymore. She sometimes never comes home. I don't know what to do; I can't look after them on my own. I "sukkel" (meaning: to struggle) to find work. If my sister doesn't cook, there is no food."

The reason for the high incidence of abuse taking place where the parents are married, is explained by Lewis (1999:113) and Ross (1995:595) who maintain that a lack of resources, for example finances, can cause stress in the relationship. The authors explain that increased stress, and low coping abilities can lead to substance abuse, which in turn can cause partner abuse. Partner abuse increases the risk of the children being physically battered as well.

Respondents $\mathrm{A}$ and $\mathrm{C}$ elaborate further on how the marital relationship contributed to the physical injury of the child in the following statements.

Respondent A: "He came home drunk again and didn't bring the money. We always fight. He never talks to me anymore, he gets angry or he walks out...he hit me before ... whenever we fight I get angry with my children too because I don't have patience for them giving me problems ..."

Respondent C: "We fight a lot about money... and he always goes to visit this other woman. This day, he didn't come home the whole week, and I know where he was. So ask him, but he say that I mustn't, like, tell him what to do. I start crying and hitting him, and he hit me back...I picked up a bottle...to throw at him, but it hit her head. I knew she was there..."

The injury to the child of Respondent $\mathrm{C}$ occurred during one of the fights, which she and her husband had, where the child was caught in the crossfire. This was a similar reason for Respondent D, where the injury occurred during one of their fights about money.

Respondent D: "I knew the child was on the bed with him, but I got so angry...I didn't think right then, I just wanted to hit him."

In conclusion to the above findings, there seems to be a lack of coping mechanisms in both single and married parents, and specifically conflict in the marital relationship, which leads to the physical injury of the child.

\section{Family composition}

The majority (eight) of physically abused children $(\mathrm{N}=24)$ came from a home where there were three children. A further six of the physically abused children came from homes where there were four children. Five children had one sibling, while the remaining five were the only child. The mean average of children per household was 2,6 .

These findings support Brissett-Chapman (1995:361) who mentions that family size does play a role in increasing the risk of physical child abuse, in that larger families, especially with four or more children, are more at risk, as are step-families. The author attributes increased caretaker and financial stress to this factor. 
All four respondents in the case studies had extended families staying with them. Respondents A and B stated that their children shared the same parents, while respondent $\mathrm{C}$ said that both children came from different fathers. Respondent A was a stepparent as well, and made the following statement on the effect her family size and composition had on her parenting:

Respondent A: "My children are all three years apart, and that helps because the older ones can help me with the young ones...and the other family help with cooking and sometimes look after the children. ...I get angry with "my step-child”...she doesn't listen like my children...she is just like her mother."

Respondent A never physically abused her own children, but had a history of repeatedly beating the step-child, reflecting a greater risk for step-children to be exposed to physical abuse.

Respondents B and C stated that living with extended family members actually helped with the workload and their parenting, while Respondent D saw them as interfering.

Respondent C stated:

"My mother often gives me advice, and looks after the children when I want to leave the house...it helps me a lot to get away from it sometimes..."

Respondent D on the other hand found that although they helped with the workload, the effect the maternal mother had on her parenting was not positive:

"...she always mixes in with what I say, and tells me how to be a mother...don't do this and don't do that!...the whole time. It makes me angry because she treats me like a child. I just give up then."

It is thus important to find out the size and composition of the family, when assessing an alleged case of intentional injuries to a child. It is not only a risk factor to consider during assessment, but also an indicator that the other siblings are in danger of being exposed to the abuse of the parent. Step- or extended families have an increased risk for physical abuse to take place. It also appears that having a larger age gap between the children is seen as having a positive effect on parenting.

\section{History of abuse in the family}

The majority (13) of the respondents $(\mathrm{N}=24)$ had a history of abuse in the home, which included spouse abuse and physical abuse as a child. The other eleven respondents said there had not been a previous incidence of physical abuse in the home. Brissett-Chapman (1995:36) and Warner and Hansen (1994:17) mention that a history of abuse in the home of the child, as well as a history of abuse to the perpetrator as a child, may be an indicator that the current injury was intentional. Other authors such as Coohey and Braun (1997:1085) and Mullen et al. (1991:18) further elaborate on this factor by stating that there is an increased risk of a parent physically abusing the child where there is physical violence between the spouses. These findings of previous studies are reflected in the case studies, where all four respondents stated that there had been emotional and physical abuse in the home where they grew up in, while Respondent D experienced sexual abuse. After exploring this topic further, the following statements explain how the history of abuse in their homes could contribute to the physical abuse of their own child:

Respondent C: "There were so many different men that came in and out of our house. We didn't even know who our father's was... My mother hit us when she drank, they would hit us too, because we were in the way. I always felt very scared and alone ... Even now, I just sometimes 'crack' and I just hit my child to teach her." 
Respondent D: "I always felt very scared. My father would be drunk a lot... and he would hit us...I never knew where to go. I don't like feeling like that anymore...I am not a child...I am now in control."

Feelings of helplessness and powerlessness experienced as a child were despised by both the respondents, and they attempted to "stop feeling like that" by acting out the role of the controlling parent. Their own parents acted as role models to this. In conclusion, discovering a history of abuse in the home of the child as well as the parents during assessment is a strong indicator that the injury incurred by the child was due to physical abuse by the parent.

\section{Substance abuse}

More than half (thirteen) of the parents/perpetrators $(\mathrm{N}=24)$ abused alcohol or other substances, and eleven stated that they did not use any substance. Two of the respondents in the case study confirmed that they abused alcohol, but mainly on weekends, while one only drank socially. Respondent A had been involved in previous physical assaults towards her partner while under the influence of alcohol, and Respondent B had been physically violent toward his previous partner and children before while under the influence of alcohol. This confirms the findings of other studies conducted by authors such as Lewis (1999:122), Mullen et al. (1996:18) and Ross (1995:595) who indicate that parents abusing substances increased the risk of physical abuse in the home.

From the above-mentioned findings, it appears that substance abuse is an indicator that the injury may have been intentional, and needs to be considered during assessment.

\section{Employment}

The majority (thirteen) of the respondents $(\mathrm{N}=24)$ were not employed, although eleven were employed. According to Howard et al. (1991:393) and Lewis (1999:122) parents that are unemployed are more at risk for abusing their children. The reason for physical abuse amongst the parents that were employed is explained by Stone (1990:72) and Warner and Hansen (1994:19). Both authors state that even though the parent may be employed, low-income is also a risk factor. There is increased conflict in low-income families, which often leads to social problems such as substance abuse, marital problems and partner abuse. Corby (1993:68) and Stone (1990:72) explain that poor families usually have limited resources to help them cope which causes these social problems. The findings of the respondents in the case studies also showed that substance abuse can increase marital conflict. Only Respondent $\mathbf{C}$ had employment, but stated that the earnings were "not enough to survive", while Respondents A, B and D had no employment. All four respondents mentioned that marital conflicts and conflicts at home were often due to these financial problems. Respondent D explained how the lack of income contributes to their marital conflict:

\footnotetext{
"We only fight on weekends when he doesn't bring home money, because he drank it all out in the shebeen (a local pub in the informal settlement communities)...I get very angry... and he gets very violent."
}

From the findings above, it is essential to consider not only whether the parent of the physically abused child is employed, but also the income of the parents in order to identify risk factors.

\section{Housing and social environment}

To further explore whether factors such as housing and the social environment contributed to the parent abusing his or her child, the responses of the respondents in the case studies were analyzed. 
Only respondent A and D stated that she was happy where she lived, while the other two were not happy. All four respondents mentioned that crime rates were very high in the area that they lived, and that they did not feel safe in that area. Respondent A had nine people living in a two-bed roomed house, respondent $\mathrm{B}$ had eight people in a two-bed roomed house, respondent $\mathrm{C}$ had four people in a one-roomed shack, while respondent D lived with seven other people in a two-bed roomed house. According to the findings in the cases of the four respondents, there is an average of four persons sharing one bedroom. These are extremely crowded living conditions where privacy is lacking. The statements of Stone (1990:72) and Lewis (1999:113) that crowded and unsafe conditions contribute to the parent's frustration and may cause them to take it out on the child, support the findings of this study.

The following statement was made by Respondent $\mathbf{C}$, which expresses a lot of frustration with her living situation and her child whose behavior causes conflict with the other housemates:

"...I can never be alone, there is always people around. And if someone fights I have to leave my own house to get away...my baby cries a lot at night, and everybody gets cross with me, because she wakes them up...they say it's my fault, but I can't help when the baby cries."

A common trend identified in the cases of all four respondents, was their lack of social contact with people, other than with the people sharing the house with them. Only respondent $\mathrm{C}$ stated that she would sometimes go to church in order to fellowship with other people. The fact that none of the respondents socialized with people other than family members is a risk factor for child abuse according to Corby (1993:76) and Coohey and Braun (1997:1083). Parents who are socially isolated and who do not socialize in the larger community are at risk for abusing their children.

All four respondents lived near to their hometown, which meant that they had family networks close by. Only respondents A, C and D mentioned that they received emotional, financial and material support and assistance with caring for the children, from the family members. Although Howard et al. (1991:393) and Coohey and Braun (1997:1083), state that having family members close by should decrease the risk of child abuse, due to the different forms of support the parents receive from them, it was however was not reflected in the case studies.

According to these findings, it appears that crowded living environments and lack of social contact are factors that contribute to the parent incurring intentional physical injuries on their children. Immigration, or distance from the hometown does not seem to play a role in intentionally injuring the child, as it occurs even with positive family support that is close-by.

\section{ASSESSMENT OF INTENTIONAL PHYSICAL INJURIES}

Assessment of physically abused children is important for confirming whether the injury was intentional, and for deciding on future intervention with the child and the family (Hartweg, 2001). Brissett-Chapman (1995:357-8) says that professionals in the medical field are struggling to identify abuse due to lack of experience or inadequate training in this area. Even Social Workers are usually ill equipped to tackle assessment of physically abused children (Brissett-Chapman, 1995:354), despite the fact that they usually co-ordinate the assessment of physically abused children (Wells, 1995:53). Argent et al. (1995:1318) and Ross (1995:1373) add that the hospital system relies on the social worker to co-ordinate and manage cases of physically abused cases. The following contains some of the findings of the final part of the study, which entailed questionnaires completed by the social workers employed at the hospital $(n=5)$. 
In this study the majority (four) of the respondents $(n=5)$ stated that there were conflicting findings amongst the team members when assessing children who had been physically abused, while one did not experience this. Two of the four respondents whose response was affirmative, explained that sometimes physicians assessed a child incorrectly as having been physically abused, or even missed diagnosing such a case. The other two respondents explained that differences often occur amongst team members on what is acceptable or non-acceptable parental discipline, and what type of discipline should be classified as physically abusive. These findings are supported by those of Blatt, Saletsky, Meguid, Church, O’Hara, Haller-Peck \& Anderson (1999:345), Kotch et al. (1993:244), Lewis (1999:198) and Wells (1995:348) who state that conflicting findings may occur between professionals as each discipline has a different frame of reference, socio-cultural and educational background. Conflicting findings can cause and inability to agree on suspected cases of physical abuse. Warner and Hansen (1994:11) and Wells (1995:351) maintain that these types of conflict amongst professionals can be overcome by collaboration, ongoing training and involvement of all team members during the assessment of physically abused children. Hartweg (2001) recommends that a standard assessment framework be drawn up by hospital teams, other child protection teams, and other professionals assessing physical child abuse based on the content of local legislation, and social, emotional, psychological and physical indicators of physical abuse which could act as a guideline. The paediatric community is looking for better ways to intervene in cases of child physical abuse.

\section{CONCLUSION}

In conclusion it can be stated that conflicting findings can prevent effective assessment and may even lead to charges being pressed incorrectly to an innocent party. It is important for the social worker, or professional conducting an initial assessment of the injury to the child, to collaborate with the other team members during assessment. This will facilitate an understanding of the psychosocial dimension of physically abused children, and to have knowledge of the factors that play a role in children being physically abused.

Research findings contained in this article reflect a wide scope of the demographic and social factors that were present in families where physical abuse of children occurred. Most of the findings correlated with the findings of studies conducted by other authors who were referred to in this report, and a few minor differences were highlighted. The information obtained from the findings will be able to give social workers and other professionals more insight into working with children and their families where there are suspected incidents of physical abuse. It is also crucial information for trained professionals currently working in the health sector and child protection teams, and ongoing training is necessary to ensure effective assessment and help for children suffering from this brutal form of abuse.

It is not always easy to establish whether an injury to a child was intentional or as a consequence of abuse. In order to do this effectively, an assessment has to be made of not only the physical injury, but also of the psychosocial circumstances of the child and his/her parents. The diagnosis of physical child abuse should be based upon physical findings and their compatibility with the obtained history and the child's level of development.

\section{REFERENCES}

ARGENT, A.C.; BASS, D.H. \& LACHMAN, P.I. 1995. Child abuse services at a children's hospital in Cape Town, South Africa. Child Abuse and Neglect, 19(10):1313-1321. 
BLATT, S.D.; SALETSKY, R.D.; MEGUID, V.; CHURCH, C.L.; O’HARA, M.T.; HALLERPECK, S.M. \& ANDERSON, J.M. 1997. A comprehensive, multidisciplinary approach to providing health care for children in out-of-home care. Child Welfare, 76(2): 331-347.

BRIERE, J.N. 1992. Child abuse trauma. Theory and treatment of the lasting effects. Newbury Park: SAGE Publications, Inc.

BRISSETT-CHAPMAN, S. 1995. Child abuse and neglect: Direct practice. Encyclopedia of Social Work $\left(19^{\text {th }}\right.$ ed). Washington: NASW Press: 353-366.

CHILD CARE ACT 74 of 1983, as amended by Act 86 of 1991. Government Gazette, no. 8765. Cape Town and Transvaal Printers for Government Printers.

COOHEY, C. \& BRAUN, N. 1997. Toward an integrated framework for understanding child physical abuse. Child Abuse and Neglect, 21(11):1081-94.

CORBY, B. 1993. Child abuse: Towards a knowledge base. Open University Press: Buckingham.

DEPARTMENT OF HEALTH 1997. White Paper for the transformation of the health system. Government Gazette, Notice 17910 of 1997. Pretoria: Government Printer.

DE VILLIERS, F.P.R. \& PRENTICE, M.A. 1996. Accumulating experience in a child abuse clinic. South African Medical Journal, 86:147-150.

DOOLEY, D. 1995. Social research methods $\left(3^{\text {rd }}\right.$ ed).. Upper Saddle River, New Jersey: Prentice-Hall.

GALLAGHER, M.M.; LEAVITT, K.S. \& KIMMEL, H.P. 1995. Mental health treatment of cumulatively/repetitively traumatized Children. Smith College Studies in Social Work, 65(3): 206-237.

GRINNELL, R.M. \& WILLIAMS, M. 1990. Research in social work. Illinois: FE Peacock Publishers.

HARTWEG, J. 2001. The identification and assessment of intentional physical injuries to hospitalized pre-school children. M.A. Thesis, University of Stellenbosch, Department of Social Work.

HOWARD, P.A.; MARUMO, L.P. \& COETZEE, D.J. 1991. Child abuse in Alexandra. A clinicbased study and a community programme. South African Medical Journal, 80:393-396.

KOTCH, J.B.; CHALMERS, D.J.; FANSLOW, J.L.; MARSHALL, S. \& LANGLEY, J.D. 1993. Morbidity and death due to child abuse in New Zealand. Child Abuse and Neglect, 17(2): 233 247.

LEWIS, S. 1999. An adult's guide to childhood trauma: Understanding traumatised children in South Africa. Cape Town: David Philip Publishers.

LOUW, H.M.; VAN SCHALKWYK, H.J.S.; BARNES, J.M.; DHANSAY, S. \& SCHAAF, H.S. 1999. Child abuse and neglect: Social work experience at Tygerberg Hospital. Social Work/Maatskaplike Werk, 35(4):301-312.

MONAGHAN-BLOUT, S. 1996. Re-examining assumptions about trauma and resilience: Implications for intervention. Psychotherapy in Private Practice, 15(4):45-68. 
MULLEN, P.E.; MARTIN, J.L.; ANDERSON, J.C.; ROMANS, S.E. \& HERBISON, G.P. 1996. The long-term impact of the physical, emotional and sexual abuse of children: a community study. Child Abuse and Neglect, 20(1):7-21.

PELTZER, K. \& PHASWANA, N. 2000. Factors influencing child abuse and neglect behavior by social workers in the Northern Province, South Africa. Social Work/Maatskaplike Werk, 36(1):69-78.

PRINO, C.T. \& PEYROT, M. 1994. The effect of child physical abuse and neglect on aggressive, withdrawn, and prosocial behavior. Child Abuse and Neglect, 18(10):871-884.

ROSS, J.W. 1995. Hospital social work. Encyclopedia of Social Work $\left(19^{\text {th }}\right.$ ed $)$ Washington: NASW Press: 1365-1377.

ROSS, S.M. 1996. Risk of physical abuse to children of spouse abusing parents. Child Abuse and Neglect, 20(7):589-598.

SMITH, S.L.; SULLIVAN, Q.E. \& COHEN, A.H. 1995. Factors associated with the indication of child abuse reports. Journal of Social Service Research, 21(1):15-34.

SOUTH AFRICAN NATIONAL COUNCIL FOR CHILD AND FAMILY WELFARE 1992. Child Abuse and Neglect $\left(1^{\text {st }}\right.$ ed). Braamfontein: SANCCFW.

STONE, M. 1990. Child protection work: A professional guide. Venture Press: Birmingham.

WARNER, J.E. \& HANSEN, D.J. 1994. The identification and reporting of physical abuse by physicians: a review and implications for research. Child Abuse and Neglect, 18(1):11-25.

WELLS, S.J. 1995. Child abuse and neglect overview. Encyclopedia of Social Work (19 ${ }^{\text {th }}$ ed). Washington: NASW Press: 346-353.

WILLIAMS, M.; TUTTY, L.M. \& GRINNELL, R.M. 1995. Research in social work. An introduction. Illinois: FE Peacock Publishers.

WINSHIP, W.S. 1987. The detection of child abuse. Free to be. Early Childhood Education. 